\title{
Fake news and covid-19: a concern due to the low vaccine coverage in Brazil
}

\section{Fake News e covid-19: uma preocupação devido à baixa cobertura de vacinação no Brasil}

\author{
Dennis Minoru Fujita ${ }^{a, b, c}$ \\ (D) https://orcid.org/0000-0003-0419-5338 \\ E-mail: d.fujitaœfm.usp.br \\ Luiz Henrique da Silva Nalic, d \\ (D) https://orcid.org/0000-0002-8365-9796 \\ E-mail: luiznaliøgmail.com \\ Giselle Pacifico Sartoria, b \\ (iD) https://orcid.org/0000-0002-2372-0559 \\ E-mail: gisellesartoriðgmail.com \\ Andrés Jimenez Galisteo ${ }^{a, b}$ \\ (i) https://orcid.org/0000-0003-1611-6721 \\ E-mail: galisteoळusp.br \\ Heitor Franco de Andrade J $r^{\mathrm{a}, \mathrm{b}}$ \\ (D) https://orcid.org/0000-0003-4697-4647 \\ E-mail: hfandradळusp.br \\ Expedito José de Albuquerque Luna \\ (D) https://orcid.org/0000-0002-1145-9672 \\ E-mail: elunaळusp.br \\ aniversidade de São Paulo. Instituto de Medicina Tropical de \\ São Paulo. São Paulo, SP, Brazil. \\ buniversidade de São Paulo. Laboratório de Investigação \\ Média (LIM49). Hospital das Clínicas da Faculdade de Medicina \\ da Universidade de São Paulo. São Paulo, SP, Brazil. \\ 'Research Group of Epidemiologic, Clinical, Molecular and \\ Cellular Aspects of Infectious Diseases-CNPQ/UNISA. São Paulo, \\ SP, Brazil. \\ dUniversidade de Santo Amaro. Programa de Pós-graduação \\ em in Ciências da Saúde. São Paulo, SP, Brazil.
}

\section{Correspondence}

Dennis Minoru Fujita

Av. Prof. Enéas Carvalho de Aguiar, 470, São Paulo, SP, Brazil.

CEP: $05403-000$.

\section{Abstract}

This study comprised the application of a survey in São Paulo, Brazil, in 2 different periods of 2020: the beginning of the covid-19 pandemic and the disease's first peak (from March to April, 100 interviews) to the time of stability in case fatality rates (from May to July, 100 interviews); the questionnaire included was composed of 14 multiple-choice questions to evaluate the importance of mass communication channels, including social media, and the level of importance attributed to preventive measures at the beginning of the pandemic.

The changes in people's behavior, even in a group with more schooling, which initially considered preventive measures to be very important (91\%) but, in the second survey, was reduced to $82 \%$.

The reinforcement of preventive measures to reduce cases and deaths by covid-19 in Brazil is urgent, allied to recommendations with clear information on the importance of vaccination to avoid low rates as the current situation of vaccine coverage for preventable diseases.

Keywords: Covid-19; Fake News; Communication; Public Health Policies; São Paulo. 


\section{Resumo}

Foi conduzida uma pesquisa em São Paulo, no Brasil, em 2 períodos distintos de 2020: sendo o primeiro no início da pandemia do covid-19 com um elevado pico de incidência da doença (de março a abril, foram realizadas 100 entrevistas) até o momento de estabilidade nas taxas de letalidade (de maio a julho, foram realizadas outras 100 entrevistas), composto por 14 questões de múltipla escolha para avaliar a importância dos canais de comunicação em massa (incluindo as redes sociais) e o nível de importância atribuído às medidas preventivas no início da pandemia.

As mudanças no comportamento das pessoas, mesmo dentro de um grupo de nível educacional alto, que inicialmente considerava as medidas preventivas muito importantes (91\%), apresenta considerável queda na segunda pesquisa realizada (redução para 82\%).

Há a necessidade urgente de reforço de medidas preventivas para redução de casos e óbitos por covid-19 no Brasil, aliadas a recomendações com informações claras como a importância da vacinação para evitar baixas taxas de cobertura vacinal que se apresentam em outras doenças preveníveis por vacinas.

Palavras-chave: Covid-19; Fake News; Comunicação; Políticas Públicas de Saúde; São Paulo.

\section{Introduction}

The vulnerable scenario for the emergence of new infectious diseases outbreaks in the XXI Century is the result of a world ultra-connected by transports between high density cities, crossing the natural boundaries, allowing greater contact with natural wildlife, a worldwide framework not limited to poor nations (Fujita et al., 2016).

In the past, the seasons with their well-defined climatic characteristics represented precisely the periodicity of many infectious diseases. However, this continuous environmental degradation and constant $\mathrm{CO}_{2}$ emission resulted in climate changes with consequent increase in global temperature that allowed the spread of many vectors of tropical diseases, and this is no longer a problem restricted to tropical areas (Castro et al., 2019).

The current SARS-CoV2 pandemic is an example of this disorderly growth situation in which an infectious disease restricted to animal hosts, including domestic, livestock and even wild, has spilled over to human transmission.

The Coronaviruses belongs to the order Nidovirales, family Coronaviridae with four genera of coronaviruses - Alphacoronavirus, Betacoronavirus, Deltacoronavirus, and Gammacoronavirus. In the XXI century, three Betacoronaviruses capable of causing severe acute respiratory syndrome have emerged: coronavirus (SARS-CoV), Middle East respiratory syndrome coronavirus - MERS-CoV, and SARS-CoV-2 (Hui; Zumla, 2019).

In December 2019, in Wuhan, China, a Novel Coronavirus (SARS-CoV-2) was detected with humanto-human transmission risk, and with a viral genome closely related to several bat coronaviruses. Only after a month, there were more than 800 reported cases with $3 \%$ of mortality rate in January 24,2020 (Perlman, 2020).

The main issue in China for the increasing in reported cases was due to the denial of the local government to identify this syndrome as a new disease (which implies in preventive measures and protocols for containment), associated to a fragile or neglected behaviour to communicate other healthcare systems, including the international health systems, becoming 
a national uncontrollable situation that promoted its transmission to other countries.

SARS-CoV2 spread to other Asian countries, and to Europe in February, following progression to the American continent. The first case of COVID-19 reported in São Paulo, Brazil was on 25 February 2020 (Rodriguez-Morales et al., 2020). Increasing to $19,632,443$ positive cases and 548,340 deaths with 1,324 deaths/day until July 23, 2021 (Brazil, 2021).

Some preventive measures have been implemented by countries in an attempt to contain its progress, and thus avoid the consequent collapse of health care systems, such as the establishment of quarantine, social distancing practices, and other effective non-pharmacological strategies to reduce the transmission, to avoid peaks of incidence, considering the non-existence of treatment to prevent/stop the development in reported cases. The vaccines were available only in the end of 2020 , at first just for developed nations, becoming a concern to the low- and middle-income economies that need to reinforce the previously mentioned strategies.

The health alerts and communication become more important in this process, but in a period of mass hysteria caused by a pandemic condition and by a lot of fake news, we need to understand the effectiveness of mass media channels and how we can increase the accessibility and credibility of this type of information. Thus, we conducted a study to improve the actual structure of communication, in preparation to the future outbreak situations in São Paulo, Brazil.

We lead a study in São Paulo-Brazil including 2 periods of 2020: from the the beginning of the outbreak to the first peak (March to April 100 interviews) and from the first peak to the time of stability in case-fatality rates (May to July 100 interviews). The interviews were composed of 14 multiple-choice questions to evaluate the importance of mass communication channels, including social media, and the level of importance attributed to preventive measures in the beginning of COVID-19 Pandemic.

The vaccine will be the promising solution to the end of SARS-CoV2 pandemic. However, the vaccination to preventable diseases have recently presented low coverage in Brazil, impacting directly in the effectiveness of this strategy in future, which is already directly affected by fake news. Therefore, this study aimed to assess the impact of mass communication channels and the strategies for a clear communication to the population regarding health and pandemics.

\section{Methods}

We conducted a study in São Paulo-Brazil including 2 periods of 2020 : from the the beginning of the outbreak to the first peak (March to April - 10o interviews) and from the first peak to the time of stability in case-fatality rates (May to July - 10o interviews).

An online form was created on the google drive and sent by invitation to over 4000 people (average of 2000 per period) on online social networks (Facebook) of the 6 authors of the survey. Additional 100 e-mails (5o per period) were sent to researchers who have direct relationship with the Institute of Tropical Medicine of São Paulo, thus generating, in the total set, a convenience sample of 200 respondents (10o per disease evolution period).

The inclusion criteria were being a resident in the municipality of São Paulo, and having answered all the questions, in addition to agreeing with the terms of the research data disclosure. The interviewee's exclusion occurred due to non-compliance with one of these items. There were no restrictions regarding levels of education, age, gender, and ethnicity.

The interviews were composed of 14 multiplechoice questions to evaluate the importance of mass communication channels, including social media, and the level of importance related to preventive measures in the beginning of outbreak and its evolution in the time of high transmission.

The proposed study of the last period concerned the vaccination strategy and current failure in vaccination coverage for other preventable diseases. As many nations are betting on this solution, we need to understand the population's adherence and how fake news could affect future vaccination coverage rates in the country.

Due to the mandatory quarantine established in São Paulo State, we conducted the interviews by social medias, and e-mail for random group of persons from 14 to 60 years that lives in São Paulo, Brazil. 
The data were processed in GraphPad Prism 9 and the study was authorized by the FMUSP research ethics committee.

\section{Results}

The two stages of our research had an intense participation of young people ( 15 to 24 years $-\mathrm{n}=1 \mathrm{O}$ / $n=21,25$ to 44 years $-n=64 / n=58$ ). This may be due to the data collection channels used in this research (Facebook and e-mail), which are more extensively

\section{Figure I - Interviewed Profile and Information/Day}

\section{Age Group}
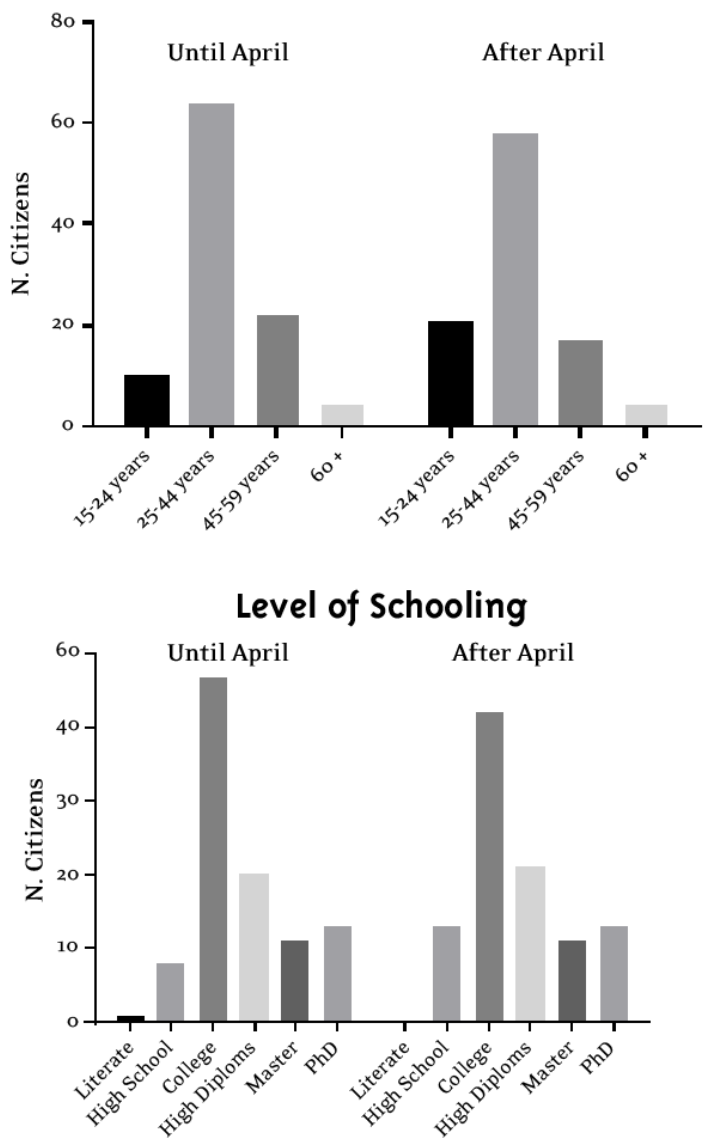

In the beginning of COVID-19 Pandemic, the amount of information received by the interviewers was extremely high with a variation of five pieces of information per day (29\%), 10 pieces of information per day (26\%), 15 pieces of information per day (10\%), 20 pieces of used among younger people. The other interviewed people $(n=26 / n=21)$ were from groups of adult and older people.

Female participation $(68 \%-59 \%)$ was higher in both stages, however, with a significant increase in male participation $(32 \%-41 \%)$ in the second stage.

The level of education from the researched group varied, as follows: College $47 \%-42 \%$; Undergraduation 20\% - 21\%; Master $11 \%-11 \%$ and $\mathrm{PhD} 13 \%-13 \%$. These results represent a reality very different from the Brazilian educational one.

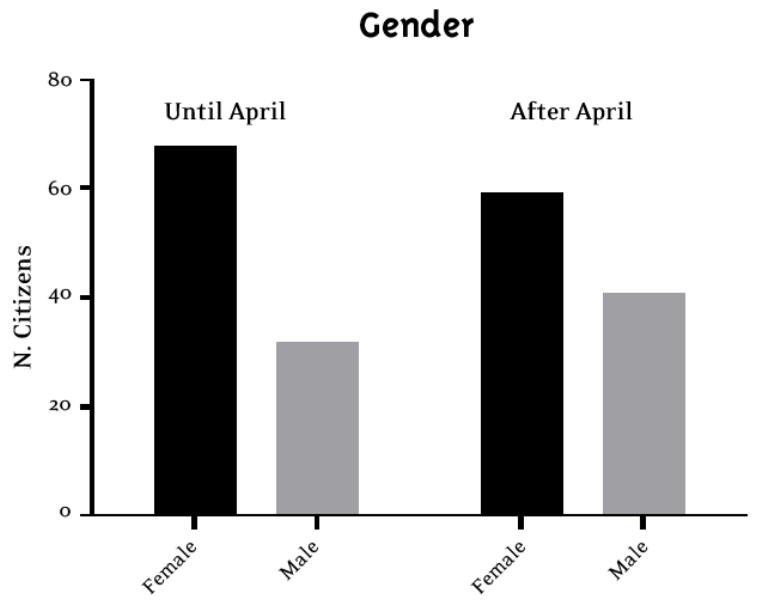

Covid-וg - Information/Day

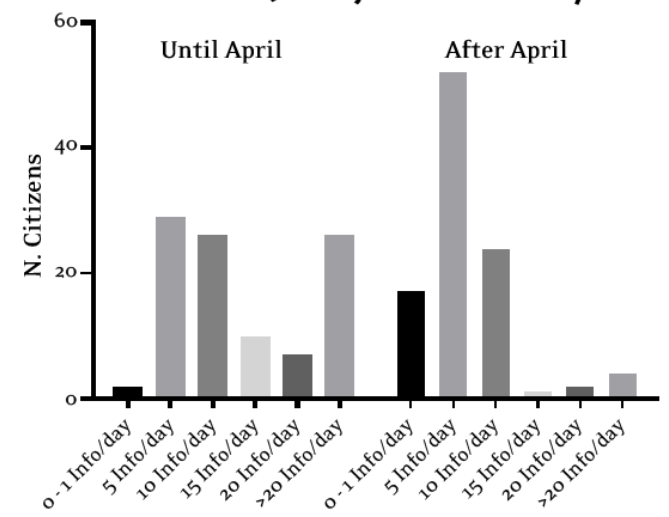

information per day ( $7 \%$ ) and more than 20 pieces of information per day (26\%). In the second search, we have a decrease in the intensity of information flow with the majority of the group receiving from five $(52 \%)$ to $10(24 \%)$ pieces of information per day about COVID-19. 
Figure 2-Media Source and Credibility
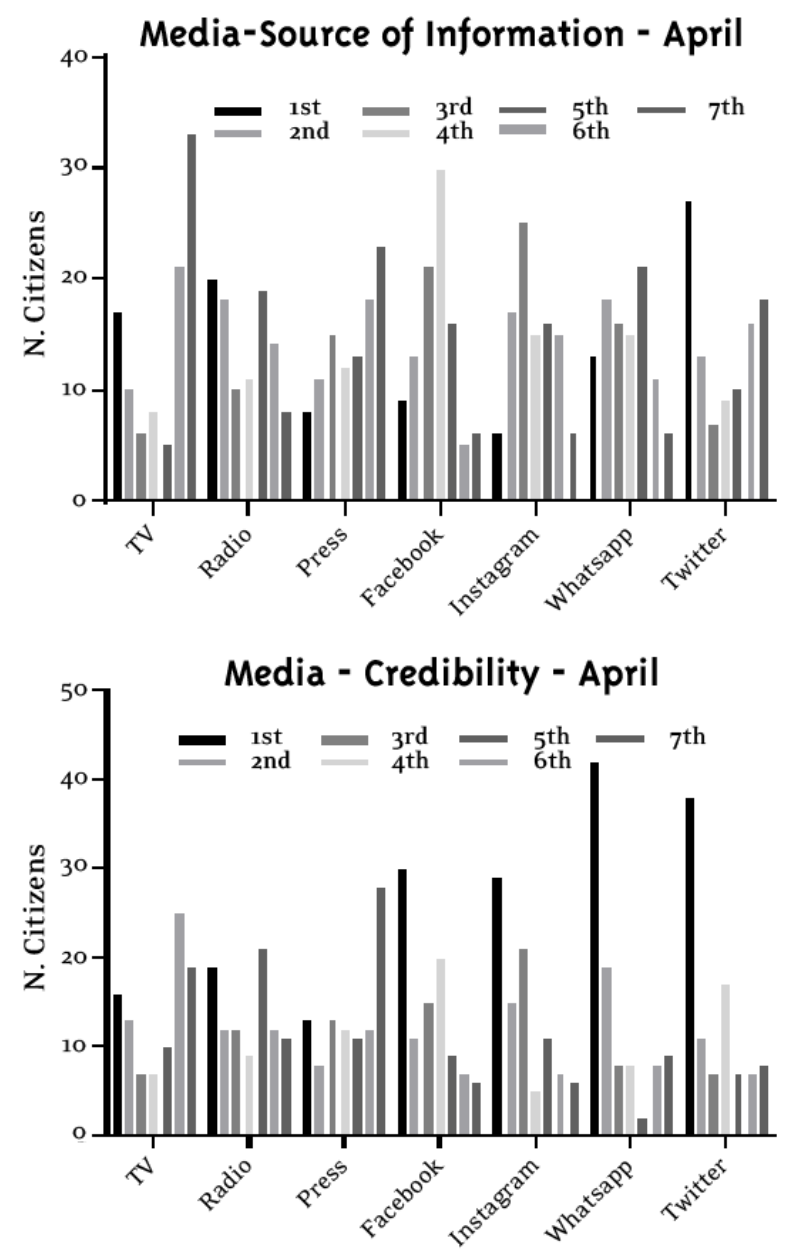

The main source of communication was Twitter $\left(1^{\text {st }}-\mathrm{n}=31 \%\right)$, followed by Open and Cable TV $\left(2^{\text {nd }}-\right.$ $17 \%)$, Press ( $\left.2^{\text {nd }}-17 \%\right)$, Radio $\left(3^{\text {rd }}-23 \%\right)$, Instagram $\left(4^{\text {th }}-24 \%\right)$, Facebook $\left(4^{\text {th }}-22 \%\right)$ and WhatsApp $\left(5^{\text {th }}-19 \%\right)$.

Regarding to the credibility of the sources, we have the following: Twitter $\left(1^{\text {st }}-27 \%\right)$, WhatsApp $\left(2^{\text {nd }}-18 \%\right) /$ Radio $\left(2^{\text {nd }}-18 \%\right)$, Instagram ( $3^{\text {rd }}-$ $25 \%)$, Facebook $\left(4^{\text {th }}-30 \%\right)$, Radio $\left(5^{\text {th }}-20 \%\right)$ and TV $\left(6^{\text {th }}-33 \%\right)$.

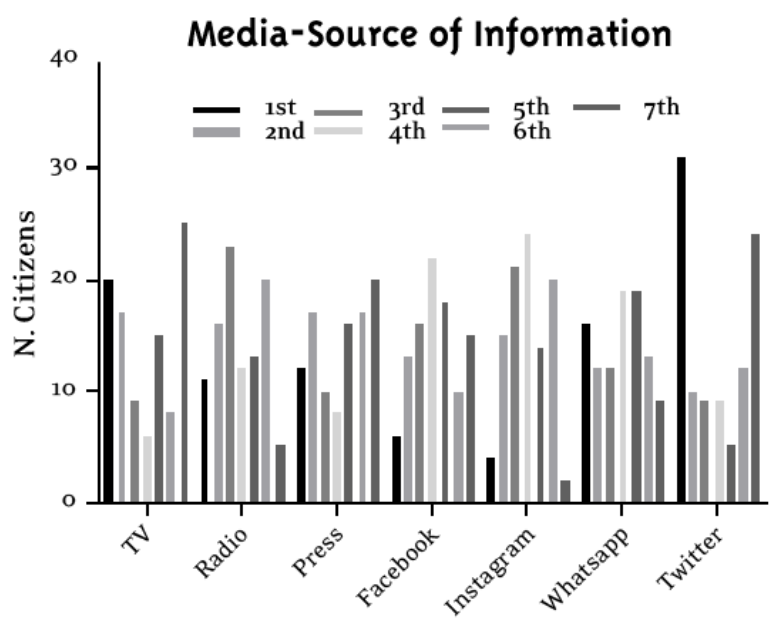

Media - Credibility

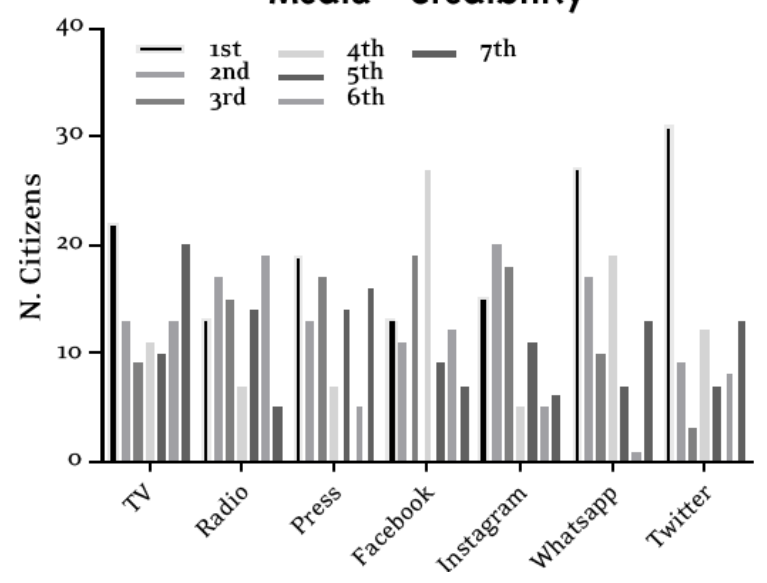

The messages about COVID-19 forwarded by interviewees to other persons occurred with the following conditions and percentages: When Come from a Reliable Person - 4\% to 7\%, Rarely or Never$36 \%$ to $53 \%$ and Only After Checking - $60 \%$ to $40 \%$.

The verification of information about covid-19 by interviewees presented a high percentage in the first moment (Yes 83\% / No 17\%). However, in the second time, there is a small drop in this process $(-6 \%)$. 
Figure 3 - Frequency, verification of Trust, Source for verification and Number of Cases/Deaths
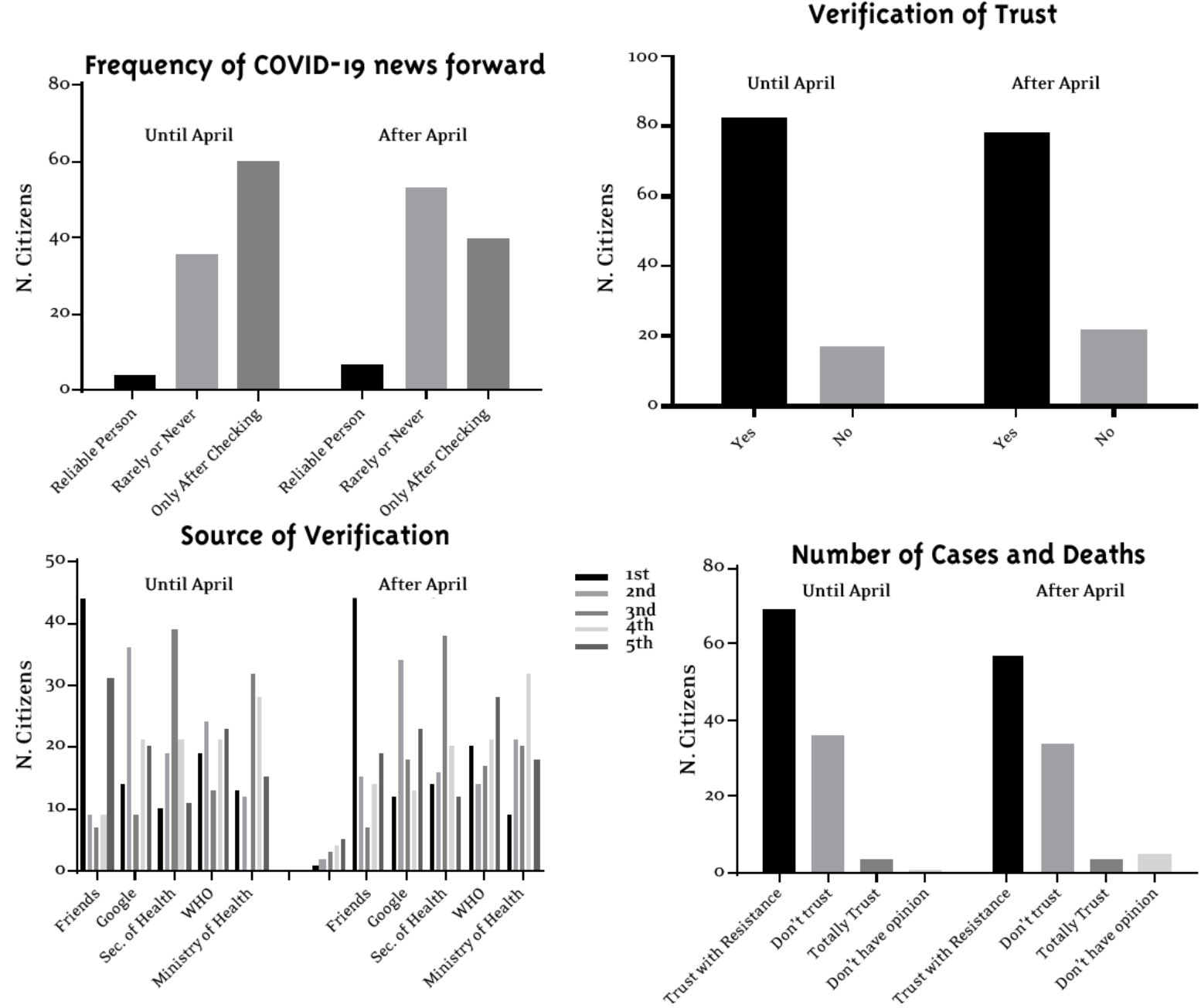

Regarding the sources used to check the information received about COVID-19, we have the following: Friends ( $\left.1^{\text {st }} 44 \%-45 \%\right)$; Google $\left(2^{\text {nd }} 36 \%-\right.$ $34 \%$ ); Secretariat of Health ( $3^{\text {rd }} 39 \%-38 \%$ ), Brazilian Ministry of Health $\left(4^{\text {th }} 28 \%-32 \%\right)$ and World Health Organization ( $5^{\text {th }} 23 \%-28 \%$ ).

Confidence for the number of positive cases and daily deaths reported by competent institutions via the different channels had the following distribution: Trust with Reluctance 69\% - 57\%;

Don't Trust $36 \%-34 \%$; Totally Trust $4 \%$ in the 2 times and Don't have opinion only $1 \%$ in the second time.

The main reason for concern regarding COVID-19, in the opinion of the interviewees, was classified as follows: High risk of transmission $60 \%-62 \%$; Hospital capacity for treatment 30\% - 28\%; Fast chronification $7 \%-2 \%$; Diseases lethality $3 \%-2 \%$; Don't have opinion o\% - $3 \%$ and Post-exposure health problems $0 \%-3 \%$. 
Mandatory Preventive Measures
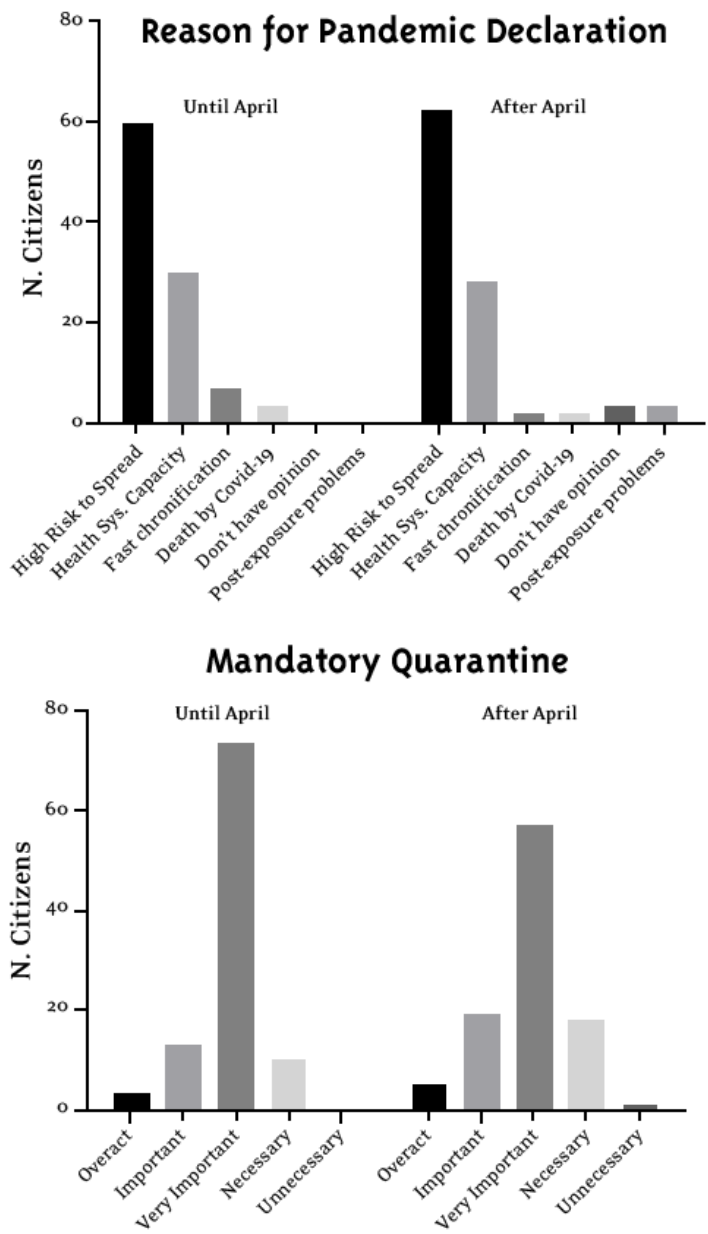

Mandatory preventive measures mainly of personal hygiene, such as washing hands, use of alcohol gel and facial mask, among others to prevent COVID-19, were classified by the interviewees as: Very important $91 \%-82 \%$; Important $6 \%-7 \%$; Necessary $2 \%-7 \%$ and Overact $1 \%-3 \%$.

Quarantine, social isolation and distancing are considered: Very important $74 \%-57 \%$; Important $13 \%-19 \%$; Necessary $10 \%-18 \%$; Unnecessary o\% $1 \%$ and Overact $3 \%-5 \%$.

The last question, included only in the second survey, considered the potential increase of COVID-19 Fake News due to the long period of restrictions, presenting the following results: increase of $25 \%$ $n=29$; increase of $50 \%-n=49$; increase of $75 \%-n=21$; and increase of $100 \%-n=1$.
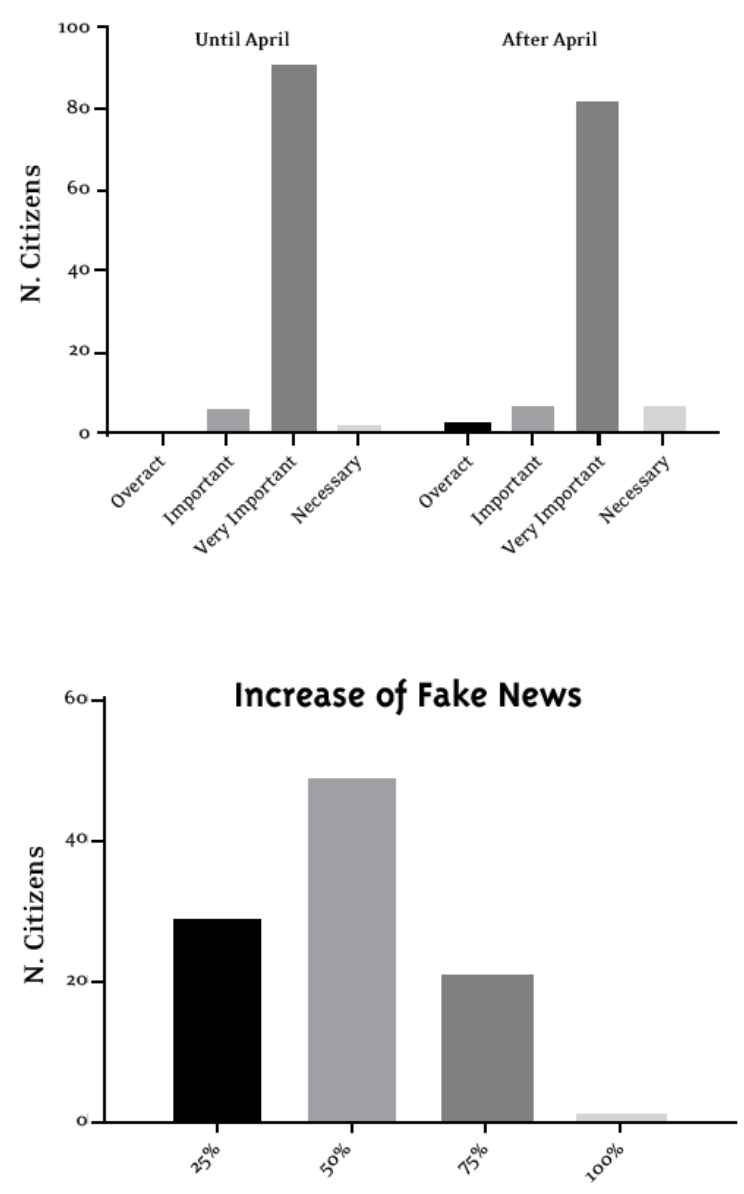

\section{Discussion}

The COVID-19 epidemic in Brazil remains high even after 17 months since the first positive case in the city of São Paulo (Melo et al., 2020). The State registered 3,991,188 confirmed cases and 136,884 deaths until July 27, 2021 (São Paulo, 2021).

Unfortunately, despite the elevated incidence plateau of COVID-19 cases (incidence of 1968,9), many Brazilian states allowed the reopening of several activities with high potential for mass gatherings, such as restaurants and bars, in addition to enabling domestic travel, which intensifies on holidays.

The local authorities were forced to grant this reopening to reduce the population's stress due to the long time of restrictions imposed as preventive 
measures, associated to a popular incredulity, and this idea becomes more acceptable due to intentional absence of a national public health policy that clarifies and effectively manages the safety of all (Zhu et al., 2020).

The spread of fake news, according to the answers of $49 \%$ of the interviewees, indicated an increase of $50 \%$ individuals being cautious since it changes people's behaviour, even from an educationally privileged group, where they initially considered preventive measures to be very important ( $91 \%)$. However, in the second survey, it shows a reduction to $82 \%$ of the group.

In this sense, more restrictive actions as quarantine and social distance lose strength. They were regarded as very important at the beginning ( $74 \%$ of the group), however, the current context presents a reduction of $\mathbf{2 2 . 9 7 \%}$ in this perception, while $1 \%$ of the group considers these actions unnecessary and $5 \%$ regards them as overacted (in the previous survey, it was only $3 \%$ ).

The increase of confirmed cases in young people by COVID-19 in Brazil may be the result of this failure in guidelines for prevention and control, with a growing movement of discredit in relation to the potential risk represented by this infectious disease. In our research, $49 \%$ of respondents considered that fake news doubled in this phase of stability, and $29 \%$ responded that such type of message increased $75 \%$.

For example, in the State of São Paulo the main age group affected by COVID-19 was the $30-$ 39 years old with 169,841 cases (23.9\%), followed by the $20-29$ years old with 116,810 cases ( $16.4 \%$ ) (State, 2020). This same scenario of young people infected can be observed on the European continent as a result of summer vacation in the Northern Hemisphere, mainly in Spain (Murillo-Llorente; Perez-Bermejo, 2020).

The unauthorized parties are other problem that may intensify the growing rates of young people infected in Brazil, because this specific age group, in many cases, do not respect the main preventive measures (Wilder-Smith; Freedman, 2020) such as the use of facial masks, social distancing, prohibition of mass gatherings and other recommendations in these parties.

Domestic trips are other important factor to the increase of incidence due to the displacement of people that favour the transmission between cities and states (Wilson; Chen, 2020).

We observe, even in a situation of pandemic, an increased flow of travellers to local tourist destinations in the holidays.

The main highway from São Paulo Capital to the Cost registered a movement of 202,800 vehicles in the Independence Day Holiday (September, $7^{\text {th }}$ ), an increase of $7.79 \%$ compared to the previous year.

It was the first important holiday after the reduction of restrictive measures imposed by municipal and state authorities, enabling the mass gatherings in these tourist destinations, as well as unauthorized parties that enhance the transmission - which had been in slow decline -, making the COVID-19 epidemic endless in Brazil.

Communication needs to be reinforced in order to avoid these situations. However, the channels of transmission should be better chosen. The old strategy of prevention campaigns on open TV does not have as much profusion and credibility as verified in our study (first source of information, but the last in credibility), being necessary to invest in digital media to inform and to be a source for accreditation of this information.

Vaccines are one of the greatest advances in medicine. After its use, diseases that were common were reduced or eradicated, saving between 2 and 6 million lives per year. But an additional 1.5 million lives could be saved if vaccination coverage were intensified (Kennedy, 2020).

Although there is no $100 \%$ effective vaccine, when used in communities with high uptake rates, collective immunity can be achieved against preventable diseases, leading them to be controlled or even eliminated (WHO, 2014).

Collective immunity, or herd immunity, occurs when a microorganism can no longer spread, as there is a proportion of the population protected from infection (Aschwanden, 2020). This population-level effect is desirable in vaccination programs, which aim to ensure herd immunity so that those who cannot be vaccinated or do not respond satisfactorily to a vaccine, such as immunocompromised ones, are protected against the respective microorganism (Randolph; Barreiro, 2020).

Brazil has one of the most extensive immunization programs in the world (Sato et al., 2020). In 1973, the 
National Immunization Program was implemented and, since then, it offers free vaccination throughout the country (Domingues; Teixeira, 2013).

However, some factors have contributed strongly to low vaccine coverage. The influenza vaccine did not reach $80 \%$ of coverage in 2020 , the first time that Brazil did not follow the recommendation of Health Authorities. The main reasons were cultural beliefs about the lack of effectiveness and side effects of the vaccine (Sato et al., 2020). Another example was the recent measles outbreak in Brazil, a consequence in the decrease in vaccine coverage among infants related to socioeconomic, political and cultural aspects, including the increase of antivaccine movements (Pacheco et al., 2019).

In 2018, Larson expressed concern about confidence in vaccines and about the flood that conveys conflicting and manipulated information on social networks. For him, this flood of misinformation should be recognized as a global threat to public health (Larson, 2018).

The proportion of the vaccinated population to achieve herd immunity depends on the infectivity of the agent (Kennedy, 2020). Herd immunity against influenza is obtained after vaccination above $80 \%$ of the population and for measles, above $90 \%$ (Karpiński et al., 2021). In the case of COVID-19, based on the infectivity of the virus, it is estimated that $70 \%$ of the population must be vaccinated in order to acquire herd immunity (Hernández; Moreno, 2020).

The COVID-19 pandemic will remain a major public health problem until herd immunity from vaccination is achieved (Ghaffari; Meurant; Ardakani, 2021). Achieving herd immunity by natural infection would be an ethical problem, especially in the absence of better patient management and without ideal protection for individuals at risk of serious complications (Fontanet; Cauchemez, 2020).

It is estimated that up to two-thirds of the world population would have to recover from the disease in order for herd immunity to be achieved, which would result in more than 30 million deaths from COVID-19 and higher mortality from other causes, which would lead to saturation the health systems (Losilla-Rodríguez et al., 2020).

Regarding vaccines against COVID-19, the WHO suggested that the efficacy has an approximate threshold of $50 \%$ and that it can be evaluated in relation to the end points of illness, serious illness and / or elimination / transmission (WHO, 2014). In fact, vaccines can contribute to the reduction and control of the disease, especially considering the lack ofeffective prophylactic drugs and few treatments (Hodgson et al., 2020).

Despite the variability of vaccines available currently, some countries that have enough vaccine for their population are unable to reach the rates of vaccination necessary for their protection due to misinformation and fake news (I et al., 2021) that probably reach the same negative results as obtained in our study. They need to extend the use of non-pharmacological preventive measures to reduce SARS-CoV2 transmission.

In Brazil, the vaccination of the population is currently compromised due to misinformation created by the Brazilian President and his government, which, due to this attitude, delayed the acquisition of vaccines, as well as promoted the doubt regarding the effectiveness of certain vaccines (Daniels, 2021), representing our greatest fear regarding to the outcome of our research.

Despite the limited number of respondents and the data collection of our survey having occurred only in 2020 , facts that could represent potential weaknesses of our research, there is the maintenance of the 2 main concerns detected in our survey: the misinformation and fake news about COVID-19, that possibly increased in the country; and the reduction in the credibility of non-pharmacological preventive measures.

There is an urgent need for the establishment of new public health policies with effective guidelines that allow sentinel surveillance in order to reduce cases and deaths from COVID-19 in Brazil, and active health recommendations with clear communication regarding the importance of vaccination and maintenance of non-pharmacological preventive measures to reduce the high rates of transmission in the country.

\section{Declaration of interests}

The authors state that they have no conflicts of interest do declare. 


\section{References}

ASCHWANDEN, C. The false promise of herd immunity for COVID-19. Nature, Berlim, v. 587 , n. 7832 , p. 26-28, nov. 2020. DOI: $10.1038 / d 41586$ o20-02948-4

BRAZIL. Coronavírus Brasil - 2021. Portal de COVID-19 do Ministério da Saúde. Disponível em: <https://covid.saude.gov.br/>. Acesso em: 23 jul. 2021. CASTRO, M. C. et al. Development, environmental degradation, and disease spread in the Brazilian Amazon. PLoS Biology, São Francisco, v. 17, n. 11, p. e3000526, 2019. DOI: 10.1371/journal.pbio.3000526

DANIELS, J. P. Health experts slam Bolsonaro's vaccine comments. The Lancet, Bethesda, v. 397, n. 10272, p. 361, 2021. DOI: 10.1016/So1406736(21)0o181-1

DOMINGUES, C. M. A. S.; TEIXEIRA, A. M. da S. Coberturas vacinais e doenças imunopreveníveis no Brasil no período 1982-2012: avanços e desafios do Programa Nacional de Imunizações. Epidemiologia e Serviços de Saúde, Brasília, v. 22, n. 1, p. 9-27, mar. 2013. DOI: 10.5123/S1679-49742013000100002 FONTANET, A.; CAUCHEMEZ, S. COVID-19 herd immunity: where are we? Nat Rev Immunol, Londres, v. 20, p. 583-584, 2020. DOI: 10.1038/ s41577-020-00451-5

FUJITA, D. M. et al. The Fast Transmission of Infectious Diseases around the World - a New Concern to the Public Health. The Brazilian journal of infectious diseases, Salvador, v. 20, n. 5, p. 513515, jan. 2016. DOI: 10.1016/j.bjid.2016.06.003.

GHAFFARI, A.; MEURANT, R.; ARDAKANI, A. COVID-19 Point-of-Care Diagnostics That Satisfy Global Target Product Profiles. Diagnostics, Basel, v. 11, n. 1, p. 115, 2021. DOI: 10.3390/ diagnostics11010115

HERNÁNDEZ, C. R.; MORENO, J. C. S. Immunity against SARS-CoV-2: Walking to the vaccination. Revista espanola de quimioterapia : publicacion oficial de la Sociedad Espanola de Quimioterapia, Madri, v. 33, n. 6, p. 392-398, 2020. DOI: 10.37201/ req/o86.2020
HODGSON, S. H. et al. What defines an efficacious COVID-19 vaccine? A review of the challenges assessing the clinical efficacy of vaccines against SARS-CoV-2. The Lancet, Londres, v. 21, n. 2, E26-E35, 2020. DOI: 10.1016/S1473-3099(20)30773-8

HUI, D. S. C.; ZUMLA, A. Severe Acute Respiratory Syndrome: Historical, Epidemiologic, and Clinical Features. Infectious Disease Clinics of North America, Bethesda, v. 33, n. 4, p. 869-889, 2019. DOI: 10.1016/j.idc.2019.07.001

I, U. et al. Myths and conspiracy theories on vaccines and COVID-19: Potential effect on global vaccine refusals. Vacunas, Amsterdã, v. 22, n. 2, p. 93-97, 2021. DOI: 10.1016/j.vacun.2021.01.001 KARPINSSI, T. M. et al. The 2020 race towards SARS-CoV-2 specific vaccines. Theranostics, [s.l.], v. 1, n. 11, p. 169o-1702, 2021. DOI: 10.715o/thno.53691

KENNEDY, J. Vaccine Hesitancy: A Growing Concern. Pediatric Drugs, Basingstoke, v. 22, n. 2, p. 105-111, 2020. DOI: 10.1007/s40272-020-00385-4 LARSON, H. J. The biggest pandemic risk? Viral misinformation. Nature, Berlim, v. 562, n. 7727, p. 309, 2018. DOI: 10.1038/d41586-018-07034-4 LOSILLA-RODRÍGUEZ, B. et al. COVID-19 natural herd immunity and risk of neuropsychiatric disorders. Revista de Psiquiatria y Salud Mental, Berlim, v. 13, n. 4, p. 228-229, 2020.

MELO, C. M. L. D. et al. COVID-19 pandemic outbreak: the Brazilian reality from the first case to the collapse of health services. Anais da Academia Brasileira de Ciências, Rio de Janeiro, v. 92, n. 4, e20200709, 2020. DOI: 10.1590/ooo13765202020200709

MURILLO-LLORENTE, M. T.; PEREZ-BERMEJO, M. Covid-19: Social irresponsibility of teenagers towards the second wave in Spain. Journal of Epidemiology, Raleigh, v. 30, n. 10, p. 483, 2020. DOI: 10.2188/jea.JE2020036o

PACHECO, F. C. et al. Trends and spatial distribution of MMR vaccine coverage in Brazil during 20072017. Vaccine, Berlim, v. 37, n. 20, p. 2651-2655, 2019. DOI: 10.1016/j.vaccine.2019.04.019 
PERLMAN, S. Another decade, another coronavirus. New England Journal of Medicine, Massachusetts, v. 382, n. 8, p. 760-762, 2020. DOI: 10.1056/NEJMe2001126

RANDOLPH, H. E.; BARREIRO, L. B. Herd Immunity: Understanding COVID-19. Immunity, Massachusetts, v. 52, n. 5, p. 737-741, 2020. DOI: 10.1016/j.immuni.2020.04.012

RODRIGUEZ-MORALES, A. J. et al. COVID-19 in Latin America: The implications of the first confirmed case in Brazil. Travel medicine and infectious disease, Amsterdã, v. 35, p. 101613, 2020. DOI: 10.1016/j.tmaid.2020.101613

SÃO PAULO. Novo Coronavírus (COVID-19) Situação Epidemiológica - 07/o9/2020. Portal da Secretaria de Estado da Saúde - Governo do Estado de São Paulo. Disponível em : <http://www.saude. sp.gov.br/resources/cve-centro-de-vigilanciaepidemiologica/areas-de-vigilancia/doencas-detransmissao-respiratoria/coronavirus/setembro/ coronaviruso70920_situacao_epidemiologica.pdf $>$. Acesso em: 7 set. 2020.

SÃO PAULO. SP registra 3,99 milhões de casos e 136,8 mil óbitos por COVID-19 | Governo do Estado de São Paulo. Portal do Governo de São Paulo, 23 jul. 2021. Disponível em: <https://www.saopaulo. sp.gov.br/noticias-coronavirus/sp-registra-399milhoes-de-casos-e-1368-mil-obitos-por-covid-19/>. Acesso em: 10 dez. 2021.
SATO, A. P. S. et al. Influenza vaccine uptake among older adults in Brazil: Socioeconomic equality and the role of preventive policies and public services. Journal of Infection and Public Health, Amsterdã, v. 13, n. 2, p. 211-215, 2020. DOI: 10.1016/j.jiph.2019.07.022

WHO - WORLD HEALTH ORGANIZATION. WHO Target Product Profiles for COVID-19 Vaccines. WHO, 9 abr. 2020. Disponível em: < https://www.who.int/publications/m/item/ who-target-product-profiles-for-covid-19vaccines >. Acesso em: 10 dez. 2021.

WHO - WORLD HEALTH ORGANIZATION. REPORT OF THE SAGE WORKING GROUP ON VACCINE HESITANCY 12 November 2014*. [s.l]:WHO, 2014. WILDER-SMITH, A.; FREEDMAN, D. O. Isolation, quarantine, social distancing and community containment: Pivotal role for old-style public health measures in the novel coronavirus (2019-nCoV) outbreak. Journal of Travel Medicine, Oxford, v. 27, n. 2, p. taaao2o, 2020. DOI: 10.1093/jtm/taaao2O WILSON, M. E.; CHEN, L. H. Re-starting travel in the era of COVID-19: preparing anew. Journal of Travel Medicine, Oxford, v. 27, n. 5, p. taaa1o8, 2020. DOI: 10.1093/jtm/taaa1o8

ZHU, D. et al. Social distancing in Latin America during the COVID-19 pandemic: an analysis using the Stringency Index and Google Community Mobility Reports. Journal of Travel Medicine, Oxford, v. 27, n. 7, p. taaa125, 2020. DOI: 10.1093/jtm/taaa125

\section{Acknowledgments}

The authors wish to acknowledge the assistance from the Institute of Tropical Medicine of São Paulo - Protozoology Lab / LIM49-HCFMUSP and Research Group of Epidemiologic, Clinical, Molecular and Cellular Aspects of Infectious Diseases - CNPQ/UNISA.

\section{Authors' contribution}

Fujita and Luna were responsible for the study design, writing and revision. Nali was responsible for data collection and writing. Sartori was responsible for vaccine research and writing. Galisteo and Andrade Jr. were responsible for data collection and revision.

Received: 09/29/2021

Resubmitted: 08/23/2021; 09/29/2021

Approved: II/08/2021 